\title{
Pulmonary arterial hypertension
}

INSERM

\section{Source}

INSERM. (1999). Orphanet: an online rare disease and orphan drug data base. Pulmonary arterial hypertension. ORPHA:182090

Pulmonary arterial hypertension (PAH) is a group of diseases characterized by elevated pulmonary arterial resistance leading to right heart failure. PAH is progressive and potentially fatal. PAH may be idiopathic and/ or familial, or induced by drug or toxin (drugor toxin-induced PAH, see these terms) or associated with other diseases like cong enital heart disease, connective tissue disease, HIV, schistosomiasis, portal hypertension (PAH associated with other disease, see this term). 